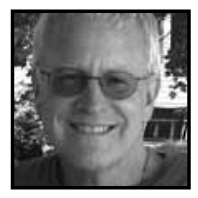

\title{
Commentary
}

\section{At the Evolving Intersection of Teaching and Technology}

Tom Snyder

\section{ABSTRACT}

In this interview, Tom Snyder recounts how his technological curiosity led him to build computers at a very young age. He describes how later, as a fifth grade science teacher, he started writing big group simulations on a RadioShack TRS80 computer, which served as the launching point for his future and ongoing career as an educational software developer. He talks about the key changes and trends he has witnessed over the past 40 years in the realms of technology, business, and education. In addition, he critically discusses the works of Vygotsky and Piaget as well as the "huge influence" that Jerome Bruner's educational path had on his life.

\section{nif) CLICK ON QUESTION TO LISTEN TO INTERVIEW}

You've been in the technology business for a long time. Can you tell us how you got started and what kinds of things you were doing in the early days in the late 1970s?

was born in 1950 and by 1962 I was perhaps North America's first true personal computer geek. A phone company went out of business near our house because they were converting over to touch-tone phones in '62. They had all these relays which were electromagnetic devices that when you turned one on, it closed another switch. I picked them up by the bushel and noticed that you could hook them up in a series... You'd turn on the first one, which would then the turn on the second one and the third, and so on. But with time I realized you could do different combinations of things with "off and on." I started creating, without really realizing it, a computer and I didn't know anything about computers. I really cut my teeth on the logic of these things. I built a little device that could count. My parents 
were... I said to them, "I want to not go to school," I think I was in the seventh grade, eighth grade, by this time. "I want to stay at home and build these things," and they said, "okay," just incredible [laughter]. (Neither one of them had done well in school.) But I built it. And then they said, "You really ought to send it to IBM." I knew that what I had was cute at best but I sent a paper description of it to IBM. I came home one day and there were crates on the front lawn of computer components that they didn't use anymore because they were doing more electronics. There were these 1950s, vintage '40s, vintage relays, and I built a bigger computer and a bigger computer still, not knowing what the hell I was doing, no training.

Then one day I was passing RadioShack—by the way I was teaching, I was teaching fifth grade, fifth grade science-but I saw a computer in the window and I thought, "You can't sell computers. These things fill gymnasiums." I bought the TRS80, which was a really early hobbyist computer-it was about six hundred bucks, which was also a lot of money. I think my take-home pay at that point was $\$ 6,900$ a year, so it was substantial. I brought it into my classroom and started messing around with it-with no intention of writing what would be called educational software, because I was not a believer... well of course!

I started making tools for myself, just record-keeping tools, things like that on this TRS80; programming in the Basic computer language you learn when you buy the computer. Then I slowly started writing tools for myself to run the big group simulations that I did in my classroom. I've always loved teaching. I had two sisters who both had some learning disabilities, an older and a younger one; it was always my task to teach them and I needed to be really gentle and careful and personal and charming and everything I could to bring them around. I was not interested in the computer as a way to teach, but as I said, it began to creep into my teaching. Before I had my computer I would run simulations and have the kids pretend to be sailing across the ocean, or to be running a factory, group simulations to get the kids talking to one another, and role-playing these fun science simulations. I realized the computer could in fact, sort of administrate that for me, so instead of me with my ice cream carton-full of paper strips with random kids' names on them and dice and a calculator...sort of me playing the role of a simulator, I could have the computer keep track of the simulation and make appropriate guesses as to what might happen next. I was free to wander among the kids and find out how their different groups were doing; each group of five kids might be a crew on a ship, or a shift in a factory, and as a group they would come up to the computer and input their decisions for the day and they'd all get some information back. The whole thing was just spectacular. After a year I had written five programs for group simulations: even one for a social 
studies teacher about African tribes migrating, looking for better farmlands, safer lands, etcetera. Then I put on a rented suit-and I mean rented-like ten bucks rent for the day, and went down to New York to McGraw-Hill. I took the day off teaching, which you didn't do, but I went down and said, "Got these things." And they said, "Oh, it's educational software." I had seen some before, which was this atrocious drone practice stuff, which is not that different from a lot of the stuff that's done today. They gave me a contract. They said, "We will buy all your five simulations and give you some real money for it." I came back and did that for a year and then finally I quit teaching and started a company. I was off and to the games, writing this groupbased software.

Can you trace for us the software evolution that you have experienced in your career to date? What are some of the milestones along the way?

Some of it was business driven. I had a company: at first it was me in the classroom and then I hired somebody and then I hired somebody else. It eventually grew to about 175 people and along the way, like any artist I suppose, you not only have your ups and downs, but you realize you have to do the kind of work you don't really want to do just to make money to pay the employees. I had a lot of young hotshot programmers from MIT and Harvard working for me. This is all out of my apartment and then I moved to another apartment. It wasn't [a] formal environment but they were real employees. I continued to make these educational group products, but there was more and more demand. Young business guys came to me; they were older than me, they were 32 or 33 and they had just graduated from Boston Consulting Group or Bain-yes the very same Bain that Mitt Romney ran. These highly prestigious consulting firms and all these young guys were coming up saying, "Educational software is going to be huge," and they had millions of dollars of venture capital. They sort of descended and said, "Could you take some of your school group simulations and make them work as home games?" I had a group simulation that I was doing for my girlfriend's classroom, even though I had finally left teaching to work full time. It was kind of a detective mystery where the kids would work in teams and go up to the computer and get information on how to solve this crime and all the different teams had different information and had to compare it. I sort of said no to the venture capitalists and they said, "That's too bad...you might make a million dollars on one of these games." And I said, "Well let me put Mr. Snyder on the phone." And I came back on the phone said, "Yes, of course I'll do that."

It really was never my intention...I'm not a big fan of kids playing games alone on computers. I actually have some theories which make me almost sound like 
an old Republican but I do believe that a massive amount of the disorders (kids and young people in their 20s and 30s even now who are still taking Ritalin) are not just based on watching television or reading too many comic books-they're rooted in the very strange experience of playing computer games. Syncing a young brain up to the clock speed of a computer has mischievous effects. But, alas, I picked up on computer games and that was an evolution for me. Our first game was a hit. There was something that was the functional equivalent of Billboard Magazine, sort of a top-40 of software and we shot right up to the top of that and started making serious money as opposed to the kind of ministry money that you would make producing at our boutique level for schools. And so the company grew and we made more games.

Then, by 1985, I said to my partner, "I want to get back to the school games. I don't want to work with these retail publishers, the Broderbunds, all these big game companies, Atari. I want to make big group simulations again. I wanted to cut all of our ties." We had Black Tuesday; we were at that point about 30 employees and we went down to seven employees. We invested all of our money in a little warehouse, and we became a publisher in our own right I believe in 1985, instead of just an author making games for what the game companies thought the public needed. We went back and became a serious educational software publisher again.

I did have milestones that came and went. You had mentioned in our last phone call that you had spoken to Jerome Bruner and he was an absolute key thinker. Watching his changes in his career really had a huge influence on the directions I went.

\section{Can you say how?}

I went to Swarthmore College, which is a very sort of intellectual place. I was a fish out of water because I was mostly interested by age 14 in girls and rock and roll, and spent a lot of my time in college recording in L.A., taking some time off college. By the end of [my] sophomore [year] I was surrounded by geniuses who knew how to talk about Karl Marx and Rosa Luxemburg, Freud and Émile Durkheim. And I didn't know anything except I had this passion for teaching. I have to mention as an aside: I read a book called "How to Survive in Your Native Land" by James Herndon, it was a book about teaching. That was what convinced me to go into teaching. My intellectual background about teaching was always self-hewn based on this one book, which is one of the neatest books I have ever read. It was honest and vulgar and told many truths about the relationship between teachers and kids, and that was how I cut my teeth in the classroom. 
But then I started trying to catch up to all I had missed at Swarthmore. Every day at lunch I would go out for two hours and start reading, and read in a dendritic format where I'd read one book and it would mention something I didn't know about, and it could be either technology or Thomas Aquinas... it didn't matter, I just read and read and read, and I've been doing it ever since, trying to become sort of an auto-didact.

I started reading a lot about education because it was my business, and I read this fellow named Jerome Bruner that everyone talked about. First I had read Piaget, which I thought was such drivel, I couldn't believe it-he was so beloved by everyone I knew or was teaching with me in schools. You could tell he was a social scientist who wished everything were more quantifiable and would surrender more gracefully to metrics somehow. He came up with cognitive stages, because at least you can count stages, stages of cognitive development. As long as you can test things and hire armies of graduate students to perform experiments identically over and over again, you can begin to mathematically define stages of learning. And I "smelled a rat" because there was something bloodless about this, that didn't seem to have much to do with what actually took place in the space between the teacher and the learner. Everyone then told me, "If you love Piaget," which I didn't, "you'll have to read Jerome Bruner," who took up the mantle for Piaget. I read Bruner who held up Piaget as the go-to pedagogical thinker, and I was astounded because Bruner seemed like such a decent and deeply intellectual soul and so gifted and so prone to questioning things. At the time I was doing one keynote a week because it was very profitable for our company. I was always on the road, so my reading took huge leaps because I was flying to every country and state I could think of, staying in a cheap hotel, giving a keynote and flying home the next day. I was reading along the way and I remember on a plane flying out to Fairbanks, it was a long flight, reading Jerome Bruner about the gifts from Piaget. I was thinking: how could Bruner, who was so gifted, so fully support this very mechanistic view of how individual kids created their own path through learning and that it all can be tracked so beautifully with math. This view was, of course, fitting in so perfectly with the computer world because to a hammer everything looks like a nail, and to a computer everything looks like data if possible. I got off the plane, and gave my usual keynote which was about what could happen with groups and what could happen with conversations between kids and between teachers and keeping that conversation alive and finding teachers who enjoy the conversation and enjoyed being with kids in many different ways, in all the different sort of intellectual ways that one can both love and be amazed by kids. Then I got back on the plane and was finishing off Bruner's book and there it was at 35,000 feet, I came to this paragraph where Jerome Bruner did what I love, when scientists 
or philosophers say, "I was wrong." He said it gingerly and carefully so as not to let down the hordes, the millions of people who adored him. He said something to the effect of, "...I might have been a bit too enthusiastic about the notions of Piaget, especially as I read Vygostky more." [And I thought]: "Oh good, I'll finish Bruner and read Vygotsky."

But Bruner did me a favour-he translated Vygotsky, and I don't mean he translated it from Russian-but from the Stalinist version of writing that Vygotsky had to do being a Russian in the 1930s, to try to figure out Vygotsky's very exciting notions about the social nature of education. And then Bruner began noticing young acolytes of his - there was a woman, I think her name was Margaret Donaldsonwho began doing Piagetian experiments that began to really take apart this Piagetian notion that, yes, if you construct the experiment perfectly, you can prove that kids can't conserve volume with water until a certain age." However, she introduced a story and narrative into the mix, wondering if there were parts of the brain that were being excluded from the Piagetian experimentation in order to make it more scientific, in order to delay any sort of false noise from the data. Instead of an experiment where water was poured into a beaker that was thinner and wider but the same amount of water and it rose to a different level and the kids would all agree that it was a different amount of water up until a magical age at which they had made a cognitive sort of quantum leap, she did the study, observing all of Piaget's exactitude and carefulness but she had a puppet involved-a naughty puppet, I believe it was her first take on this thing. I forget exactly how she structured it but it didn't break any of the rules that graduate students had been following for 30 years to make the testing accurate, but it did introduce a little bit of fiction in the background about the puppet. When the puppet would suggest that the water amount was the same amount as the other water, the kids would go, "No, it isn't!" This was a very exciting moment because it was bringing back from 10,000 years ago the notion that narrative has an incredibly powerful neurological story to tell, and social story to tell, and that we might have been draining the blood out of an understanding of how learning takes place in order to accommodate this need for science to be physics-based.

There are so many people who are thrilled that the computer could fit into this world of one-on-one classrooms where you're getting kids from one stage to the next and then they actually began convincing people that there was enough artificial intelligence available to make this one-on-one computer tutoring feasible... because, they hoped, the computer could actually be making rational judgments about whether the kids were ready to leap to the next cognitive place. I thought that was all nonsense then-I do now. Thank you Jerome Bruner and your path, and then 
my subsequent path to understanding the power of other things other than total rational deconstruction of how the child learns. It's that space that Vygotsky actually defines as ZPD [zone of proximal development], the space between the learner and the teacher. I'm sorry if I'm being a bit long-winded but I might say that the Piagetian/computer view fit in perfectly with deconstructionists and the post-modernists who were very excited by the computers that were coming out, who were trying to dethrone authority and take the author out of the light, or the teacher out of the mix, and put the teacher back in now as only a guide on the side. They were saying it's not really about that space between what the teacher does and the students know, but it's about everybody creating their own singular path through knowledge, and no sort of leadership or as I would say, master story-teller. Sadly though, the promise of tutorial computing continues on to where we are today.

Where is the digital world going when it comes to education and what kind of challenges do we really have to attend to?

I believe firmly that there are going to be accidental discoveries, which is the only way it can ever really be done in technology as it becomes more and more ubiquitous...it's an unending parade of ubiquity. Since the beginning, there was no way we were going to discover what worked with computers in a classroom through a scientific process. I don't think Seymour Papert could do it with Logo or any of the other geniuses that came along. If I had to guess where the discoveries are going to be, there's going to be a return in technology to powerful human teaching. I think that's despite all of the money that's being spent today. There is another ed-technology bubble right now-even with ed incubator start-ups. There is so much money out there for educational technology right now, but it is no different...zero lessons have been learned as far as I'm concerned. It reminds me of all the days from the 70s when there were big companies trying to take over educational software and had systems where all the student data would be kept in Omaha. Every 10 years there is an attempt to consolidate and say, "We finally know on a megalithic scale how to monitor and guide the learning of students electronically." That's happening again and a lot of money is going into it-Rupert Murdoch throwing money into educational technology in the millions, in the tens and perhaps hundreds. The big publishers, like Pearson and others, are rushing into that vacuum and everyone's trying to figure out how to cash in.

But meanwhile, there's this strange and wonderful thing going on: everything from the very low-tech thing of "Khan academy" where there's a guy who 
basically hides himself in a closet and is a polymath himself and etches out instruction for students, but he's a gifted teacher in that he moves at the right pace and you can hear him thinking out loud, in a way that is very intuitive. Or MIT and Harvard and other universities investing a lot of money in infrastructure to get their best teachers out there in the ether. There is an interesting confluence, which is, on the one hand, there's still this misguided belief that, "Finally, we can solve the problem of bad teachers by having software," then at the same time, with bigger broader networks, there's the idea that, "There is no substitute for a great teacher and how can we get more of them out there digitally."

Ultimately, the solution to the problem of bad teachers or not enough teachers or not enough good teachers, will not be not great software-it will be more great teachers. That is going to creep back in. That has to be solved. I think the "accidental discovery" is going to be that despite Wireless Generation...despite the educational tracking and training...despite that money, we're going to keep on collapsing back into the great teachers, the great storytellers, and what it takes to understand that space between teachers and students. And how technology might promote that.

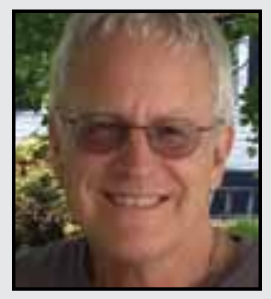

Tom Snyder is a creative and energetic teacher who began using a computer in his classroom 30 years ago to help him do what he loved to do most: teach. Tom began designing computer programs in the 1970s to enhance the collaborative learning environment in his classes. In 1980, Tom united his passion for teaching with his vision for education to establish Tom Snyder Productions. As founder and former chairman and head designer, Tom designed numerous award-winning software products including Timeliner; Fizz \& Martina's Math Adventures; Geography Search; and Decisions, Decisions, a 1997 winner of the prestigious Codie Award for excellence in technology. 